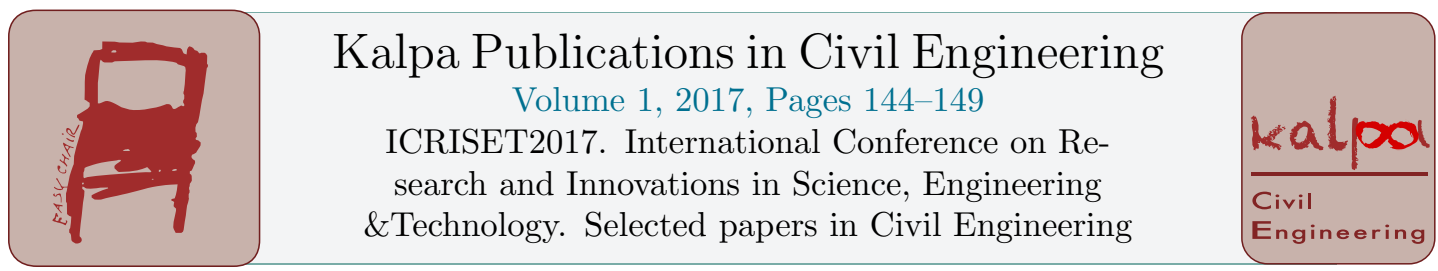

\title{
Study of Retained Stability on Warm Bituminous Mix
}

\author{
Shaleha I. Vahora ${ }^{1}$, Prof. C. B. Mishra ${ }^{2}$ \\ M.Tech Transportation Engineering student, Department of Civil \\ Engineering, BVM Engineering College, V.V.Nagar, Anand, India. ${ }^{1}$ \\ Associate Professor, Department of Civil Engineering, BVM \\ Engineering College, V.V.Nagar, Anand, India. ${ }^{2}$
}

\begin{abstract}
WMA refers to the procedure of asphalt creation at temperature lower than hot mix asphalt by the addition of additives. An endeavor is rolled out to assess the improvements in designing properties of the VG30 with and without warm additive. Likewise Marshall Mix configuration is done on VG30 for DBM layer with and without warm blend added substance evotherm $\mathrm{J} 1$ in reasonable measurements of $0.3 \%$, $0.4 \%$ and $0.5 \%$ at lower temperature according to the arrangements of codal practice, with no compromise with quality.

The impression of tests proposes the capable inclination to go for using warm mix additives into the standard of clearing things so that the temperature is cut down to $120^{\circ} \mathrm{C}$ with no compromise in quality.
\end{abstract}

Keywords: WMA (warm mix asphalt), dense bitumen macadam (DBM), Marshall Mix, Evotherm J1 chemical, aggregates.

\section{INTRODUCTION}

Warm Mix Technology developed across the world is focused towards field applications and laboratory results in terms of merits and demerits compared with HMA (Hot mix asphalt). Warm Mix Asphalt (WMA) is a quick rising new innovation which has a capability of upsetting the creation of black-top mixtures at lower temperatures. Expanding concerns on environment, rising vitality costs, a worldwide temperature alteration, and nursery impact, coupled with expanded development costs prompted the advancement for new development by the Asphalt business to create Asphalt Concrete (AC) asphalts.

\section{LITERATURE REVIEW}

Now- a day's Warm Mix Bitumen (WMA) is broadly use everywhere throughout the world as a result of its quantities of points of interest when contrasted with Hot Mix Bitumen (HMA). Literature study supporting the work is as shown:

Anand Sampath (2010) studied the inclusive evaluation result of Sasobit, Evotherm J1 and Rediset TM related to flow number, viscosity, dynamic modulus, tensile strength and dampness. 
Benjamín Colucci, evaluate additives Evotherm M1, Kaoamin 14, Sasobit and Rediset in WMA. Susceptibility to moisture results showed that Evotherm M1 with a TSR of $96.1 \%$ has less probability to stripping.

Brian D Prowell, Graham C. Hurley, Everett crews (2007), predefined that warm mix added substance conveyed by an emulsion methodology were surveyed under animated stacking in three total territories of the National Center for Bitumen Technology Test Track and used as the surface mix for two of the segments. Evotherm was combined into the same mix used heretofore on the track. Set up densities of the WMA surface layers were proportional to or superior to the hot-mix dark top (HMA) surface layers, despite when compaction temperatures were diminished by 8 to $42{ }^{\circ} \mathrm{C}$.

Graham C. Hurley \& Brian D. Prowell(2006) study was to determine the applicability of Evotherm technology in Warm Mix Asphalt(WMA) applications by performing a laboratory study including typical environmental conditions and paving operations, and to found out the performance of the mixes in high temperature conditions and quick traffic turn-over situations.

Lee $\boldsymbol{\&}$ Kim, evaluate various WMA products with respect to their fundamental engineering properties and performance-related characteristics. And put the Evotherm J1 at 4th rank out of 10 products.

MeadWestvaco (2003) performed research centre study to decide relevance of Evotherm for paving operation utilizing total size PG 64-22. He found out that expansion of Evotherm as an added substance reduce air pollution at $46 \%$ decrease in $\mathrm{CO} 2,81 \%$ in SOx and $63 \%$ in $\mathrm{CO}$.

Yu Kuang (2012) assessed the implementation of Evotherm $3 \mathrm{G}$ by focussing initially on Evotherm-J1 and Evotherm-M1 to determine the impact of dampness anti-strip.

Yi Wang, Jingwen Zhu, Liping Liu, Lijun Sun study about the asphalt rubber mixture containing Evotherm and the effect of gradation on the high temperature performance and water stability of that mixture.

\section{MATERIALS AND METHODOLOGY}

3.1 Aggregates: Natural aggregates are generally taken out from larger rock formations through an open excavation (quarry). Mechanical crushing is done to reduced extracted rock into the usable sizes. It is obtained from Savli.

3.2 VG30 (50/70 grade): It is VG system based on fundamental engineering parameter (not empirical) and possess excellent bonding and adhesive properties with aggregates, excellent property of waterproofing, resistance to acids and alkali too.

3.3 Warm Mix Additive - Evotherm J1: Evotherm J1 is WMA added substance grew by MeadWestvaco Asphalt Innovations, U.S., and France. This is a smell free, warm blend added substance that has been built to give essentially profits over current WMA advancements by lowering the production and compaction temperatures, while at the same time serving as an antistrip by improving the dampness resistance of asphalts. Evotherm $\mathrm{J} 1$ offers temperature decreases relying upon the properties of the blend. Evotherm $\mathrm{J} 1$ has air quality - stack and job-site emissions in addition to lowering temperatures and removing odours.

\section{METHODOLOGY}

In this work Dense Bituminous Macadam (DBM) mix is designed for $26.5 \mathrm{~mm}$ nominal size of aggregate. The bitumen grade VG30 is collected from IRB Plant Gujarat. Evotherm J1 chemical WMA additives collected from MeadWestvaco Asphalt Innovations, U.S., France .The aggregates are obtained from IRB plant, Pij chokadi, Nadiyad.

Initially, to find the physical properties of aggregate, laboratory test are done by performing tests as per the MoRTH specification for DBM grade 2 section 500 clause 505.In the same way, the 
Bitumen tests for VG30 with \& without WMA additives (chemical) are perform which includes the Penetration test, Viscosity test, Softening Point test, Specific Gravity etc. which are as per IS standard and all results satisfied the IS specification.

Furthermore, Marshall Mix design for DBM Grade II is worked out to determine the Optimum bitumen content $(\mathrm{OBC})$ for which other samples are prepared at $110^{\circ} \mathrm{C}, 120^{\circ} \mathrm{C}, 130^{\circ} \mathrm{C}$ temperature and at different dose of Evotherm J1 i.e. $0.3 \%, 0.4 \%, 0.5 \%$ of weight of binder. From this the Optimum temperature and Optimum dose of Evotherm J1 are found out.

Performance evaluation of DBM Grade II design has been carry out by conducting various tests on warm mix sample which include Retained stability, and Refusal Density Test.

\section{A. Laboratory investigations:}

In order to authentify the acceptance of materials required tests are carried out as per codal provision (table $1 \& 2$ ): Gradation of aggregate meeting MoRTH section 508

Table 1: Physical properties of Aggregate

\begin{tabular}{|c|c|c|c|c|}
\hline \multicolumn{5}{|c|}{$\begin{array}{c}\text { Physical Properties for Coarse Aggregate for Dense Bituminous Macadam Grade II } \\
\text { (As per MoRTH Table : 500-8) }\end{array}$} \\
\hline Sr.no & Property & Test & Specification & Result \\
\hline \multirow{3}{*}{1} & \multirow{3}{*}{ Cleanliness } & \multirow{3}{*}{$\begin{array}{l}\text { Grain size } \\
\text { analysis }\end{array}$} & \multirow{3}{*}{$\begin{array}{l}\text { Max } 5 \% \\
\text { passing } 75 \\
\text { micron is- } \\
\text { sieve }\end{array}$} & $\begin{array}{c}\text { Pass.26.5-Ret. } 22 \mathrm{~mm} \\
0.33 \%\end{array}$ \\
\hline & & & & $\begin{array}{l}\text { Pass.2.5-Ret.14 } \\
0.45 \%\end{array}$ \\
\hline & & & & $\begin{array}{l}\text { Pass.14- Ret. } 80.79 \\
\%\end{array}$ \\
\hline 2 & Practical Shape & $\begin{array}{c}\text { Flakiness \& } \\
\text { Elongation } n \\
\text { Indices }\end{array}$ & $35 \% \max$ & $27.79 \%$ \\
\hline 3 & Strength & $\begin{array}{l}\text { Aggregate e } \\
\text { impact value }\end{array}$ & $27 \%$ Max & $12.36 \%$ \\
\hline 4 & $\begin{array}{l}\text { Resistance to } \\
\text { Abrasion }\end{array}$ & $\begin{array}{l}\text { Los angles } \\
\text { abrasion test }\end{array}$ & $30 \%$ Max & $18.20 \%$ \\
\hline 5 & $\begin{array}{c}\text { Water } \\
\text { absorption } n \\
\text { value }\end{array}$ & $\begin{array}{c}\text { Water } \\
\text { absorption } n \\
\text { test }\end{array}$ & $2 \%$ Max & $0.98 \%$ \\
\hline
\end{tabular}

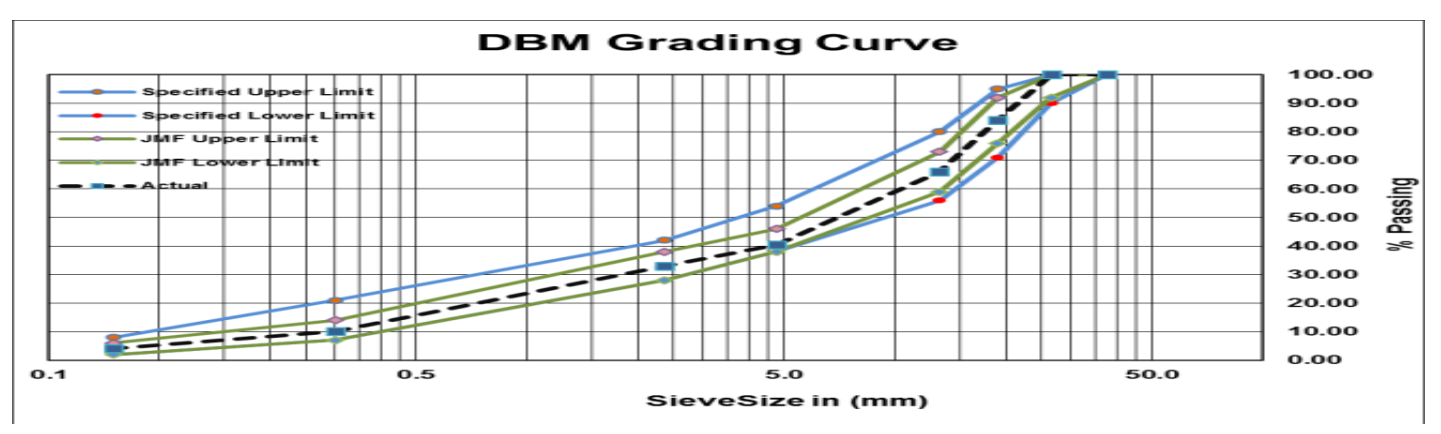

Fig. 1: Gradation of aggregate chart

It is clear from the above table that the limits are within the Upper and Lower limits satisfying JMF \& MoRTH specifications for $26.5 \mathrm{~mm}$ nominal size of aggregate.

\begin{tabular}{|c|c|c|c|c|c|c|}
\hline Table 2: Physical properties of VG 30 and VG30+\%Evotherm J1 & Code \\
Characteristics of tests: & VG-30 & $\begin{array}{c}\text { VG-30+ } \\
0.3 \% \\
\text { Evotherm J1 }\end{array}$ & $\begin{array}{c}\text { VG-30+ } \\
0.4 \% \\
\text { Evotherm J1 }\end{array}$ & $\begin{array}{c}\text { VG-30+ } \\
\begin{array}{c}0.5 \% \\
\text { Evotherm J1 }\end{array}\end{array}$ & Min. Limit & IS 1203 \\
\hline Penetration (mm) & 53.33 & 34 & 42 & 43 & $50 / 70$ & IS 1205 \\
\hline Softening point (C $\left.{ }^{\circ}\right)$ & 52.5 & 54 & 55 & 54 & 47 & IS 1208 \\
\hline Ductility (cm) & 94 & 85 & 82 & 85.5 & 40 & 2400 \\
\hline $\begin{array}{c}\text { Absolute Viscosity at } 60 \\
\left(\mathrm{C}^{\circ}\right)\end{array}$ & 4640 & 3500 & 3340 & 2810 & IS 1206 (part 2) \\
\hline $\begin{array}{c}\text { Kinematic Viscosity at } \\
135^{\circ} \mathrm{C}(\mathrm{cst})\end{array}$ & 652 & 580 & 545 & 460 & 350 & \\
\hline
\end{tabular}




\section{B. Marshall Mix design for optimum binder content using VG30}

For deciding the Optimum Bitumen Content, 6 specimens are arranged of bitumen substance at 4, 4.2, 4.4, 4.6, 4.8 and $5.0 \%$ of degree blend weight at blending temperature $160^{\circ} \mathrm{C}$ according to the system and prerequisites of MoRTH segment 508. The volumetric properties obtained are as shown in table 3 .

Table3: Properties of Marshall Mix Design for DBM Grade II as per MoRTH.

\begin{tabular}{|c|c|c|c|c|c|c|c|c|}
\hline \multirow{3}{*}{$\begin{array}{l}\% \\
\text { Bit. } \\
\text { By } \\
\text { Weig } \\
\text { ht of } \\
\text { Mix }\end{array}$} & \multirow{3}{*}{$\begin{array}{l}\text { Bulk } \\
\text { Sp. } \\
\text { Gr. } \\
\text { (Gm } \\
\text { b) }\end{array}$} & \multirow{3}{*}{$\begin{array}{l}\text { Stabili } \\
\text { ty } \\
\text { (KN) }\end{array}$} & \multirow{3}{*}{$\begin{array}{c}\text { Voids } \\
\text { in } \\
\text { Miner } \\
\text { al } \\
\text { Agg. } \\
\text { VMA } \\
(\%)\end{array}$} & \multirow{3}{*}{$\begin{array}{l}\text { Voids } \\
\text { Filled } \\
\text { with } \\
\text { Bitum } \\
\text { en } \\
\text { VFB } \\
(\%)\end{array}$} & \multirow{3}{*}{$\begin{array}{c}\mathrm{F} 10 \\
\mathrm{w} \\
(\mathrm{m} \\
\mathrm{m})\end{array}$} & \multirow{3}{*}{$\begin{array}{l}\text { Air } \\
\text { Voi } \\
\text { ds } \\
\text { VA } \\
(\%)\end{array}$} & Parameters & Binder Content \% \\
\hline & & & & & & & Stability (KN) & 4.62 \\
\hline & & & & & & & Bulk Sp, Gravity & 4.60 \\
\hline 4.00 & 2.49 & 10.75 & 15.29 & 48.84 & 2.17 & 7.82 & & \\
\hline 4.20 & 2.50 & 12.03 & 14.85 & 56.77 & 2.47 & 6.42 & VA\% & 4.63 \\
\hline 4.40 & 2.52 & 13.16 & 14.56 & 63.05 & 2.93 & 5.38 & & \\
\hline 4.60 & 2.53 & 13.30 & 14.45 & 68.22 & 3.43 & 4.59 & VFB $\%$ & 4.64 \\
\hline 4.80 & 2.52 & 13.72 & 14.87 & 72.15 & 3.80 & 4.14 & Avvo & 462 \\
\hline 5.00 & 2.52 & 12.46 & 15.36 & 74.41 & 4.40 & 3.93 & Ave, & \\
\hline
\end{tabular}

Optimum bitumen content: $4.62 \%$

The ideal cover substance $4.62 \%$ fulfils the point of confinement set down in MoRTH segment 509 regarding greatest steadiness, Marshall Flow value, maximum stability, percentage air voids in compacted mix and voids filled with bitumen and ,Bulk specific gravity. Fig. 2 shows narrow range of acceptable bitumen content.

C. Marshall Mix Design for VG30 (4.62 \% OBC) plus EvothermJ1 for optimum dosage and optimum temperature. Different dosage of Evotherm J1 are taken i.e. 0.3\%, 0.4\%, and $0.5 \%$ of Evotherm J1.

Graphs of all properties of each mix are plotted as shown in figure 2 to 6 .

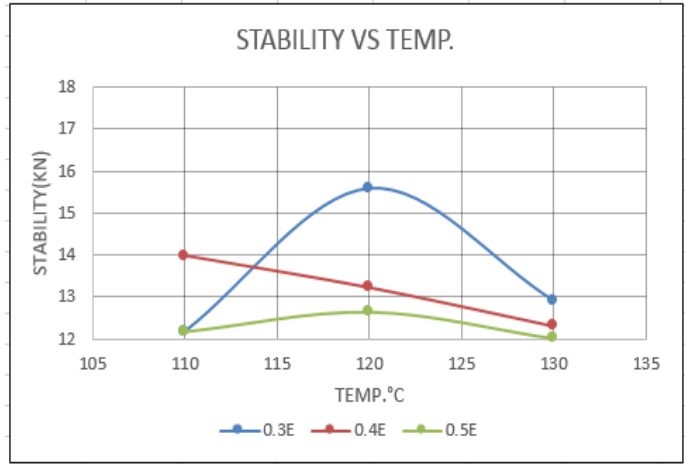

Fig. 2: Stability V/S Temperature

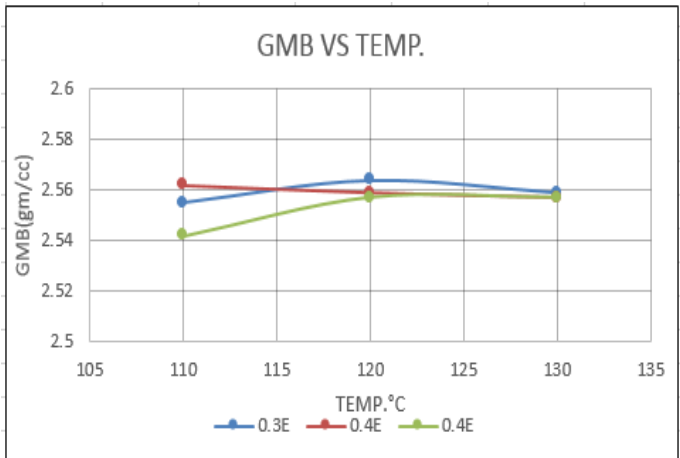

Fig. 3: Bulk DensityV/S Temperature 


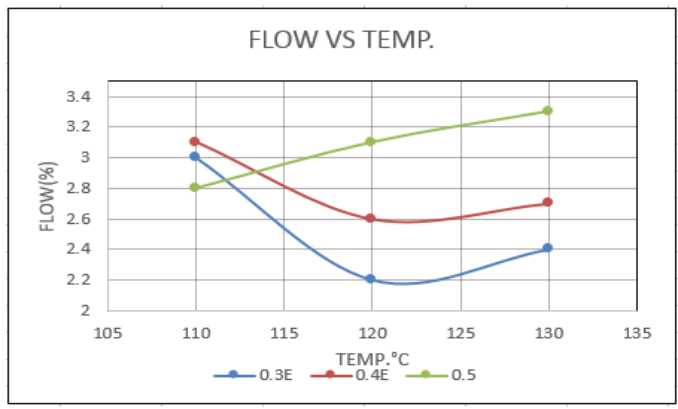

Fig. 4: Flow V/S Temperature

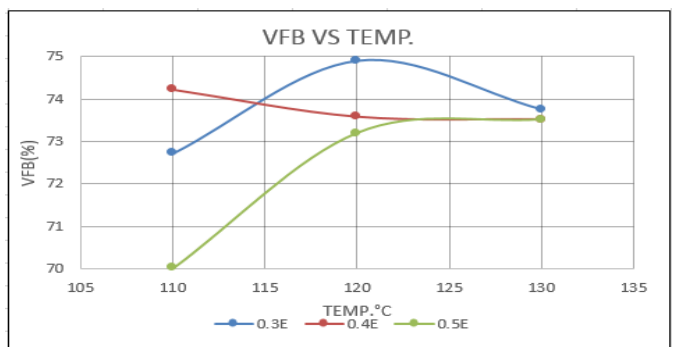

Fig. 6: \%VFB V/S Temperature

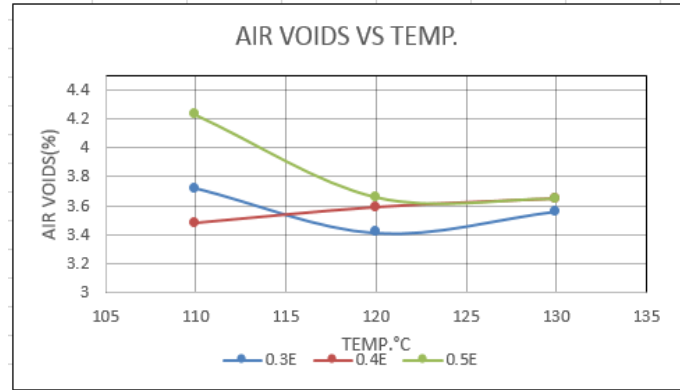

Fig. 5: \% Air Voids V/S Temperature

D. Retained Stability: It is conducted on the Marshall samples to the measure the resistance of mix towards the moisture. The stability is determined after placing the samples in water bath at $60^{\circ} \mathrm{C}$ for half an hour and 24 hours. Table 4 shows the summary of Retained Marshall Stability test results.

Table 4: Retained Marshall Stability Test Results

\begin{tabular}{|c|c|c|}
\hline Retained stability $\mathrm{KN}$ & VG30 & $\begin{array}{c}\text { VG30+0.3\% } \\
\text { Evotherm J1 }\end{array}$ \\
\hline $\begin{array}{c}\text { Marshall Stability at } 60^{\circ} \mathrm{C} \text { for } 30 \\
\text { min }\end{array}$ & 16.24 & 13.62 \\
\hline Marshall Stability at $60^{\circ} \mathrm{C}$ for $24 \mathrm{hrs}$ & 14.32 & 15.23 \\
\hline Retained Stability, $\%$ & $88.17 \%$ & $89.4 \%$ \\
\hline
\end{tabular}

E. Refusal Density: It is a simply procedures for ascertaining the air voids level when the mix has achieved its maximum density under Marshall Compaction (or any other type of compaction). For refusal density testing the Marshall Specimens have been made with the modified aggregate grading at the design Asphalt content, giving different compactive efforts ranging from 100 to 500 blows and the Air voids of the mixes have been determined from $\mathrm{G}_{\mathrm{mm}}$ (Maximum Specific Gravity of the Mix) and $\mathrm{G}_{\mathrm{mb}}$ (Bulk Specific Gravity of the mix) values (table 5)

Table 5: Refusal Density Test Results for VG30+0.3\% Evotherm J1

\begin{tabular}{|c|c|c|c|c|c|c|}
\hline $\begin{array}{c}\text { No.of } \\
\text { blows on } \\
\text { each side }\end{array}$ & $\begin{array}{c}\text { \%bit.by } \\
\text { wt. Of mix } \\
\text { sample }\end{array}$ & Temp. & $\begin{array}{c}\text { Height of } \\
\text { specimen in } \\
\text { mm }\end{array}$ & $\begin{array}{c}\text { Sp.Gravity.of } \\
\text { volume } \\
\text { Gm/cc(GMB } \\
\text { ) }\end{array}$ & $\begin{array}{c}\text { Theoretical Max } \\
\text { Sp..gravity.of } \\
\text { sample(GMM) }\end{array}$ & $\begin{array}{c}\text { \% Air voids } \\
\text { (VA) } \\
\text { G=(F- } \\
\text { E)/F*100 }\end{array}$ \\
\hline A & B & $\mathrm{C}$ & $\mathrm{D}$ & $\mathrm{E}$ & $\mathrm{F}$ & $\mathrm{G}$ \\
\hline 100 & 4.62 & $130^{\circ} \mathrm{C}$ & 60 & 2.565 & 2.65 & 3.37 \\
\hline 200 & 4.62 & $130^{\circ} \mathrm{C}$ & 59 & 2.567 & 2.65 & 3.30 \\
\hline 300 & 4.62 & $130^{\circ} \mathrm{C}$ & 58 & 2.57 & 2.65 & 3.18 \\
\hline 400 & 4.62 & $130^{\circ} \mathrm{C}$ & 57.7 & 2.573 & 2.65 & 3.06 \\
\hline 500 & 4.62 & $130^{\circ} \mathrm{C}$ & 57.3 & 2.573 & 2.65 & 3.12 \\
\hline
\end{tabular}




\section{CONCLUSION}

From the different examinations completed in the laboratory taking after, conclusions are drawn:

- Aggregate gradation chart plot in figure1, shows that the obtained gradation line falls above the lower limit line which means that the selected Aggregate proportion are more towards fine aggregate line.

- The properties of VG30 grade is investigated like penetration test, viscosity test, softening test, specific gravity and Ductility fulfilling the criteria as laid down in codal provisions for bituminous surface.

- For VG 30 Marshall Mix Design DBM Grade II, the optimum binder content comes out to be $4.62 \%$ satisfying the permissible limits as per the MoRTH section 508.

- The properties of VG30 grade $+\%$ additives (EvothermJ1) is investigated like penetration test, viscosity test, specific gravity, softening test, and Ductility test fulfilling the criteria as laid down in codal provisions for bituminous surface.

- The corroborative test of Marshall Mix design utilizing VG 30 as $4.62 \%$ by weight of bitumen with $0.3 \%, 0.4 \%$ and $0.5 \%$ Evotherm $\mathrm{J} 1$ as warm mix added substance demonstrates that VG 30 with 0.3 $\%$ Evotherm J1 fulfils the criteria's set down in codal MoRTH procurement at $120^{\circ} \mathrm{C}$, likewise it is seen that at this rate huge change in flow values, stability, and unit weight are watched for improving the compaction and increasing the workability conditions.

- The experimental test has been proved that the increase in the compactive energy shows an increase in the bulk density and decrease in the air voids level. 400 blows are obtained as the refusal density. A refusal density result with reference to air voids ascertains the mix to have attained maximum density. Comparing the threshold lower level of air voids ( 3 percent), it can be referred that the mix is not prone to rutting from the consideration of secondary compaction of traffic.

- For retained stability test under normal and wet conditions, it is observed that the retained stability increases with addition of Evotherm J1which signifies the effect of additive on resistance to moisture induced damage. This test measures the stripping resistance of a bituminous mixture.

\section{REFERENCES:}

[1]Anand sampath(2010), "Comprehensive evaluation of four warm asphalt mixture regarding viscosity, tensile strength, moisture sensitivity, dynamic modulus and flow number" University of lowa.

[2] Brian D Prowell, Graham C. Hurley, Everett crews 1(2007) Field Performance of Warm-Mix Asphalt Transportation Research Record Journal of the Transportation Research Board (Impact Factor: 0.44). 01/2007; 1998(1):96-102. DOI: $10.3141 / 1998-12$

[3] Devendra K. Patel, Prof. C. B. Mishra, Prof. A. A. Amin (2014), “ Evaluation of Rediset as Warm Mix Adhesion Promoter with CRMB 60 in Mix Design” International Journal of Engineering Research and Technology Vol. 3 (03), 2014.

[4] IS: 1202- 1978, "Methods for testing tar and bituminous materials: determination of specific gravity".

[5] IS: 1203-1978, "Methods for testing tar and bituminous materials: determination of penetration".

[5] IS: 1205- 1978, "Methods for testing tar and bituminous materials: determination softening point".

[6] IS: 1206- 1978, "Methods for testing tar and bituminous materials: determination of viscosity"

[7] IS: 2386 (Part 1) - 1963, "Methods of test for Aggregates for concrete: Particle size and shape".

[8] IS: 2386 (Part 3) - 1963, "Methods of test for Aggregates for concrete: specific gravity, density, voids, absorption and bulking".

[9] IS: 2386 (Part 4) - 1963, "Methods of test for Aggregates for concrete: Impact value and Abrasion value".

[10] IS: 15462- 2004, "Polymer and Rubber Modified Bitumen- Specification".

[11] IS: SP 53- 2002, "Guidelines on the use of Polymer Modified Binder Specifications".

[12] MeadWestvaco (2003), Evotherm warm mix asphalt-The next-generation sustainable paving solution. (www.majeskaassociates.com/ images/ Evotherm.pdf)

[13] Ministry of Road Transport and Highways (MORTH), Government of India for Road and Bridge works, section 508, Design of Bituminous Concrete.

[14] Rohith N., J.Ranjitha (2013) “A Study on Marshall Stability Properties of Warm Mix Asphalt Using Zycotherm A Chemical Additive”, International Journal of Engineering Research \& Technology (IJERT) Vol. 2 Issue 7, July - 2013.

[15] Prithvi Singh Kandhal (2010) Warm Mix Bitumen Technologies: an overview Journal of Indian Road Congress.

[16] Yu Kuang (2012) Evaluation of Evotherm as a WMA technology compaction and anti-strip additive M.tech thesis, Iowa State University, Ames, Iowa. 